\title{
Making Chemistry Fun to Learn
}

\author{
Chun Wu, Jordan Foos \\ Mount Marty College, USA
}

\begin{abstract}
The major challenge that confronts undergraduate chemical education in US is the gap between the high demands that learning requires and the low efforts that students make partially due to the lack of motivation. This paper reports strategies to ameliorate student learning in the following areas: application of friendly presentation, utilization of analogies and correlation with everyday life. The novelty lies in the attempt to incorporate new meanings into the existing platforms on publisher provided teaching resources by utilizing commercially available software tools. The paper aims to point out ways to effective knowledge delivery that can be implemented by other chemistry instructors. The goal is to make chemistry vivid and easy to understand in order to stimulate students' intellectual curiosity, which in turn leads to learning enhancement regardless of their career choices.
\end{abstract}

\section{Introduction}

Chemistry is a fundamental discipline that accounts for life at the molecular level. Nevertheless, chemistry instruction at undergraduate level in US faces the challenge that a majority of the students taking chemistry are neither motivated nor interested in this subject. Most students taking chemistry do not plan to pursue a career in chemistry. They take chemistry simply because those courses are prerequisites for degrees in fields of their interests, medical science or pharmacy or nursing for instance. Hence, lack of incentives is a profound obstacle to learning. On the other hand, chemistry contains an abundant amount of abstract concepts, which necessitates significant time and effort commitments from the students. The contrast between the low inputs and high demands results in unsatisfactory performance on the students' side and frustration on the instructor's side.

Although the motivation enhancement in chemistry career demands national efforts in terms of promoting science and technology, increasing job opportunities, improving salary dynamics etc., a student's interest is another motive that is not justifiable from an economic perspective. For instance, some kids practice for hours in their spare time creating arts, playing instruments, or perfecting their skills in sports simply because they are interested in those practices. Thus, chemistry instructors may also improve students' learning by inspiring students' interest. The question is that "is chemistry really interesting?” Ironically, the answer is only "yes" to a limited number of chemists but not to the general public due to the adoption of tedious teaching methods in chemical education. Our goal is to expose the fascinating side of chemistry to our students and inspire their curiosity regardless of their career choices.

Traditional approaches on how to improve chemistry teaching at the post-secondary level have been discussed in quite a few books in the area of achieving effective teaching and enhancing students' problem solving skills [1-4] and novel strategies come out every day in attempts to fill in the entirety [5-8]. However, not many resources address ways to show the vivid nature of chemistry. This paper reports several means of fulfilling this goal.

\section{Methods}

The three methods that we use within this research are discussed in Sub-sections 2.1, 2.2 and 2.3.

\subsection{Use Friendly Presentation}

Presentation is the heart of the teaching process. The best way of getting students excited in chemistry is by presenting it in a dynamic manner. Instructors may buttress the lectures with the combination of boards and audio-visual aids such as overhead transparencies, PowerPoint slides and videos, etc [5] that makes chemistry more alive and real to the students as our millennium students are mostly visual learners due to the image-centric, visual world in which they are raised. Students grasp the concepts better if they can picture them. Thanks to the development of computer-related technology, we are able to show pictures of everything, from the giant solar system to a tiny atom, to the students, which in turn induce more straightforward perception. There is an increasing trend that textbook publishers nowadays provide JEGs, PowerPoint slides and transparencies of lecture outlines with the recent upsurge of textbook companion sites. 


\subsection{Illustrate with analogies}

Even the most abstract concepts in chemistry can be illustrated by examples or by analogies. It is beneficial to include as many analogues as possible to illustrate basic concepts in the lectures. It takes time to prepare but it is extremely rewarding. In this way, students are able to correlate sophisticated concepts in chemistry with easy to comprehended analogies. Figures 1-6 represent various examples of illustrations and analogies.

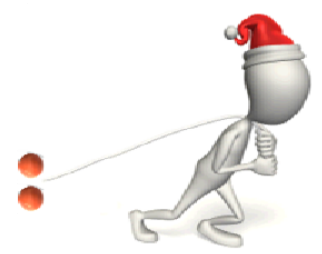

Figure 1. Illustration of an electronegative atom or group. The electronegative atom or group is shown as a cartoon character pulling a pair of electrons with the rope. The electrons are shown as red balls. (Modified from Jupiterlmages (c) 2009 utilizing Paint $\odot$ 2009 )

Figure 1 was used to illustrate electronegativity [10] in general chemistry and the property of electron withdrawing groups in organic chemistry by comparing electronegative elements or electron withdrawing groups to a cartoon character pulling a pair of electrons with the rope.

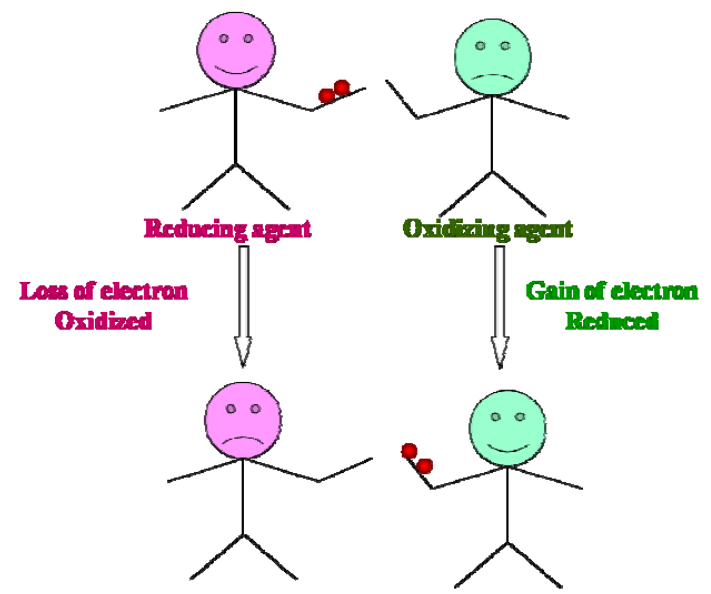

Figure 2. Illustration of the redox reaction. The electrons are shown as red balls in cartoon characters' hands. (Created utilizing ChemDraw ${ }^{\mathrm{TM}}$, CambridgeSoft)

Figure 2 indicated the nature of redox (shorthand for reduction-oxidation) $[11,12]$ reactions in which electrons are donated from the reducing reagent to the oxidizing reagent. Electrons can be liken to red balls in the reducing reagent's hand.
Electron delocalization [13] is the origin of a variety of chemical concepts such as the size and resonance effect on acidity, the source of aromaticity [14] and the driving force of electrophilic aromatic substitution reactions [15], etc. We may draw an analogy between electron delocalization and mass distribution, which is more straightforward. The contrast in size between a fluorine ion and iodine ion is displayed as an ant $v$. s. a human in Figure 3a in which lack of stability can be visualized through the fact that the cartoon ant caries an apple in a nervewracking way while the cartoon human carries it very easily. Figure $3 \mathrm{~b}$ demonstrates that electron delocalization stabilizes a species. The fact that a cartoon character finds it easier to carry two small bags of money than carrying all the money in one bag symbolizes a resonance stabilized anion in which the negative charge is shared by two oxygen atoms.

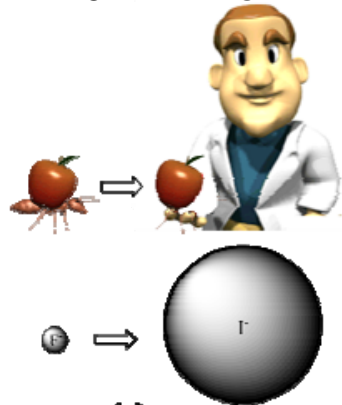

(a)

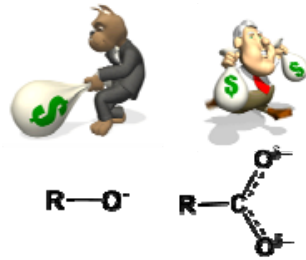

(b)
Figure 3. Illustrations of electron delocalization. (a) Stability difference between a fluoride ion and an iodide ion. The atomic sizes are represented by an ant and a human, respectively. The electrons are shown as apples of the same size. (b) Stability difference between an alkoxide ion and a carboxylate ion. One big money bag represents one full negative charge on oxygen in an alkoxide ion while each of the two small money bags represents that each oxygen atom in a carboxylate ion bears a one-half negative charge. (Modified from Jupiterlmages (c) 2009 utilizing ChemDraw ${ }^{\mathrm{TM}}$, CambridgeSoft and Paint $($ 2009)

Michaelis-Menten kinetics ${ }^{[16]}$ applies to a number of biological kinetic processes, such as facilitated diffusion, simple enzyme catalytic reactions. However, comprehending hyperbolic saturation pattern is a hard nut to crack for students. Figure 4 depicts the facilitated diffusion and its connection to an analogy. Think of carrier proteins as vehicles that carry passengers to the destination, and think of the passengers as transported species. If the number of vehicles stays still (i.e. two on the diagram), increasing the number of passengers will not increase the transport rate because only two passengers will be transported per ride and the rest of the passengers have to wait for their turns. Thus, the transport rate reaches saturation. It is easy for students living in the "country on wheels" to understand that when the passenger number is larger 
than the vehicle number, the number of passengers no longer determines the transport rate. The same analogy applies to simple enzyme catalytic reactions too.

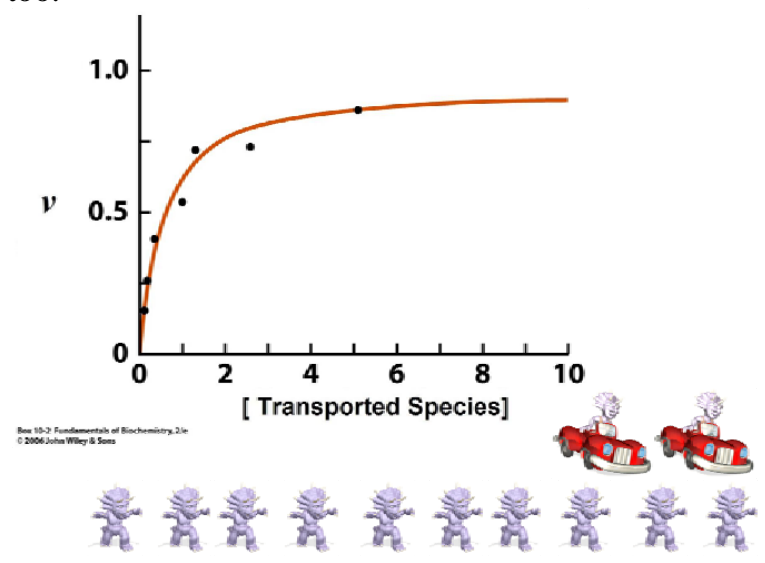

Figure 4. Illustrations of Michaelis-Menten kinetics in facilitated diffusion. The carries proteins are shown as red convertibles and the transported species are shown as dinosaur passengers, respectively. (Modified from box 10-2 Fundamentals of Biochemistry 2e (C)2006 John Wiley \& Sons and Jupiterlmages @ 2009 and Paint@ 2009)

Orbital hybridization is a theory initiated by Linus Pauling [17] for the rationalization of molecular geometry of organic compounds. Comprehending it is another hard nut to crack for students. Figure 5 endows pancakes making with a

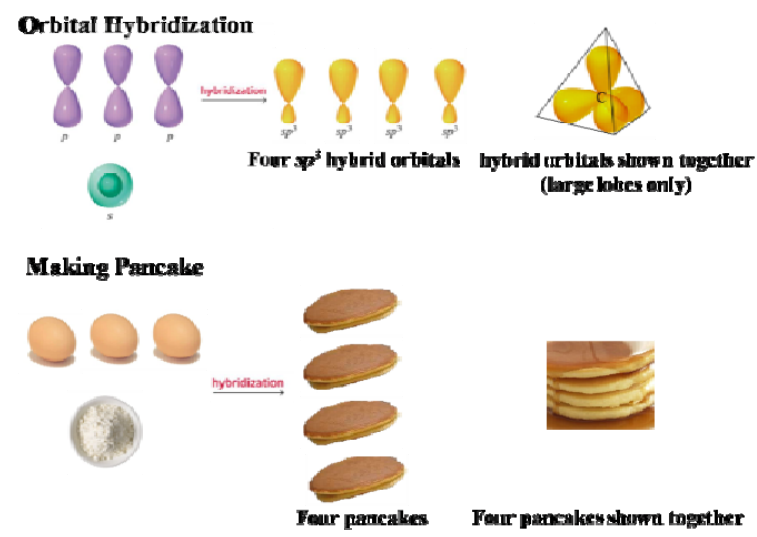

Figure 5. Illustrations of orbital hybridization. The original orbitals are to hybridized orbitals what eggs and flour are to pancakes. (Modified from Biochemistry 5e @2007 Prentice Hall and JupiterImages $(2009$ and Paint $\odot$ 2009)

symbolic meaning of orbital hybridization. The original orbitals are to hybridized orbitals what eggs and flour are to pancakes. For example, one does not see individual eggs and flour in a pancake as they are all mixed together and each pancake in figure 5 contains a quarter of flour and three quarters of egg.
For the same principle, each $s p^{3}$ hybridized orbital contains $1 / 4 \mathrm{~s}$ characters and $3 / 4$ p characters.

\subsection{Correlate with everyday life}

Chemistry touches all aspects of our lives. An experienced instructor is able to connect the depth of the science of chemistry with its every-day-life importance. There are articles [1] and books [2-4] about the everyday life chemistry. Table 1 summarizes a series of examples that I incorporate in my classes. Albeit correlation chemistry with everyday life appears in almost every textbook, none of the textbooks summarizes examples in such a table form in which substantial resources are listed in just two pages.

\section{Table 1. Selected everyday life correlated chemical concepts}

\begin{tabular}{|c|c|}
\hline Concepts & Everyday life Connection \\
\hline Density & $\begin{array}{l}\text { HDL and LDL - good and bad } \\
\text { cholesterol? }\end{array}$ \\
\hline $\begin{array}{l}\text { Second law of } \\
\text { thermodynamics }\end{array}$ & $\begin{array}{l}\text { Why is it easy to stay messy while } \\
\text { hard to keep neat? }\end{array}$ \\
\hline Colligative properties & Why does salt melt ice? \\
\hline Intermolecular forces & $\begin{array}{l}\text { Why is oil liquid and butter solid at } \\
\text { room temperature? }\end{array}$ \\
\hline Geometric isomerism & Formation of trans fat in cooking oil \\
\hline Stereoisomerism & $\begin{array}{l}\text { What is the difference between } \\
\text { Prilosec and Nexium? }\end{array}$ \\
\hline Micelles & How does soap clean? \\
\hline Micelles & $\begin{array}{l}\text { What is the role of bile salts during } \\
\text { fat digestion? }\end{array}$ \\
\hline precipitate & What is soap scum? \\
\hline precipitate & What is hard water? \\
\hline Oxidation reaction & Why is the statue of liberty blue? \\
\hline Oxidation reaction & How does rust work? \\
\hline Catalytic hydrogenation & Manufacturing of Margarine \\
\hline Base catalyzed hydrolysis & How is soap made? \\
\hline Acid catalyzed hydrolysis & $\begin{array}{l}\text { How do drug-sniffing dogs detect } \\
\text { illegal drugs? }\end{array}$ \\
\hline $\begin{array}{l}\text { Nucleophilic addition- } \\
\text { elimination }\end{array}$ & How does penicillin work? \\
\hline Chromic acid oxidation & How do breathalyzers work? \\
\hline $\begin{array}{l}\text { Nucleophilic addition- } \\
\text { elimination }\end{array}$ & How is aspirin made? \\
\hline Concepts & Everyday life Connection \\
\hline $\begin{array}{l}\text { Nucleophilic addition- } \\
\text { elimination }\end{array}$ & How is nylon 6-6 made? \\
\hline Polymerization of alkenes & How is plastic made? \\
\hline Polymerization of alkenes & How is PVC made? \\
\hline Polymerization of alkenes & How is Teflon made? \\
\hline Hydrophobic effect & $\begin{array}{l}\text { Why do small oil drops in water } \\
\text { tend to aggregate together into larger } \\
\text { ones? }\end{array}$ \\
\hline $\begin{array}{l}\text { Oligosaccharides and } \\
\text { antigen-antibody complex }\end{array}$ & $\begin{array}{l}\text { What role do blood types play in } \\
\text { blood transfusions? }\end{array}$ \\
\hline Structure of lipids & Health benefits of Omega-3 fish oil \\
\hline $\begin{array}{l}\text { Lipid membrane fluidity } \\
\text { and temperatures }\end{array}$ & $\begin{array}{l}\text { Why deep ocean fish contain more } \\
\text { unsaturated fatty acids? }\end{array}$ \\
\hline $\begin{array}{l}\text { Semi- permeable } \\
\text { membrane, osmosis and } \\
\text { diffusion }\end{array}$ & $\begin{array}{l}\text { How does a kidney dialysis machine } \\
\text { work? }\end{array}$ \\
\hline $\begin{array}{l}\text { Contrast between steroid } \\
\text { and peptide hormones }\end{array}$ & $\begin{array}{l}\text { Why do the risks of hormone } \\
\text { therapy outweigh the benefits for } \\
\text { most women? }\end{array}$ \\
\hline
\end{tabular}




\begin{tabular}{|c|c|}
\hline Isoelectric point & How is cheese made? \\
\hline Protein primary structure & How do meat tenderizers work? \\
\hline Protein primary structure & $\begin{array}{l}\text { How different is human insulin from } \\
\text { porcine insulin? }\end{array}$ \\
\hline $\begin{array}{l}\text { Protein tertiary structure- } \\
\text { disulfide bond }\end{array}$ & $\begin{array}{l}\text { What is involved in a "hair } \\
\text { permanent"? }\end{array}$ \\
\hline $\begin{array}{l}\text { Fibrous and globular } \\
\text { Proteins }\end{array}$ & $\begin{array}{l}\text { Why is hair water insoluble while } \\
\text { egg white soluble? }\end{array}$ \\
\hline Protein Denaturation & $\begin{array}{l}\text { Why is raw egg white water soluble } \\
\text { while cooked egg white insoluble? }\end{array}$ \\
\hline Protein Denaturation & Why does alcohol sterilize things? \\
\hline Protein Denaturation & $\begin{array}{l}\text { Why must we wear goggles in the } \\
\text { lab? }\end{array}$ \\
\hline Hemoglobin and Iron & $\begin{array}{l}\text { Why is venous blood dark red while } \\
\text { arterial blood bright red? }\end{array}$ \\
\hline Myoglobin & Why is beef red while fish white? \\
\hline Glycoproteins & $\begin{array}{l}\text { Why do we need to do "type and } \\
\text { crossmatch" test before a blood } \\
\text { transfusion? }\end{array}$ \\
\hline Antigens and antibodies & $\begin{array}{l}\text { Why do we need to do "type and } \\
\text { crossmatch" test before a blood } \\
\text { transfusion? }\end{array}$ \\
\hline Enzyme specificity & $\begin{array}{l}\text { How is it possible that humans } \\
\text { cannot digest grass while cows can? }\end{array}$ \\
\hline Concepts & Everyday life Connection \\
\hline Enzyme specificity & What causes lactose intolerance? \\
\hline Enzyme binding model & $\begin{array}{l}\text { Why is Nexium more effective than } \\
\text { Prilosec? }\end{array}$ \\
\hline Competitive inhibition & $\begin{array}{l}\text { How do sulfonamides fight bacterial } \\
\text { infection? }\end{array}$ \\
\hline Substrate analogues & $\begin{array}{l}\text { How do sulfonamides fight bacterial } \\
\text { infection? }\end{array}$ \\
\hline $\begin{array}{l}\text { Noncompetitive } \\
\text { inhibition }\end{array}$ & $\begin{array}{l}\text { Why are heavy metals a Hazard to } \\
\text { your health? }\end{array}$ \\
\hline Irreversible inhibition & $\begin{array}{l}\text { How does penicillin fight bacterial } \\
\text { infection? }\end{array}$ \\
\hline Irreversible inhibition & How does aspirin work? \\
\hline Bacteriostatic antibiotics & $\begin{array}{l}\text { How do sulfonamides fight bacterial } \\
\text { infection? }\end{array}$ \\
\hline Bactericidal antibiotics & $\begin{array}{l}\text { How does penicillin fight bacterial } \\
\text { infection? }\end{array}$ \\
\hline $\begin{array}{l}\text { Metabolism---oxidative } \\
\text { decarboxylation }\end{array}$ & $\begin{array}{l}\text { How does thiamine (vitamin } \mathrm{B}_{1} \text { ) } \\
\text { work? }\end{array}$ \\
\hline $\begin{array}{l}\text { Metabolism ---citric acid } \\
\text { cycle (CoA) }\end{array}$ & $\begin{array}{l}\text { How does pantothenate (vitamin } B_{5} \text { ) } \\
\text { work? }\end{array}$ \\
\hline $\begin{array}{l}\text { Metabolism ---citric acid } \\
\text { cycle }\left(\mathrm{FAD} / \mathrm{FADH}_{2}\right)\end{array}$ & $\begin{array}{l}\text { How does riboflavin (vitamin } \mathrm{B}_{2} \text { ) } \\
\text { work? }\end{array}$ \\
\hline $\begin{array}{l}\text { Metabolism ---citric acid } \\
\text { cycle }\left(\mathrm{NAD}^{+} / \mathrm{NADH}\right)\end{array}$ & How does niacin (vitamin $\mathrm{B}_{3}$ ) work? \\
\hline $\begin{array}{l}\text { Metabolism --- } \\
\text { gluconeogenesis }\end{array}$ & How do biotin supplements work? \\
\hline $\begin{array}{l}\text { Fate of Pyruvate ---lactate } \\
\text { fermentation }\end{array}$ & $\begin{array}{l}\text { Why do muscles get sore after } \\
\text { vigorous exercise? }\end{array}$ \\
\hline $\begin{array}{l}\text { Fate of Pyruvate --- } \\
\text { ethanol fermentation }\end{array}$ & How is liquor made? \\
\hline Recombinant DNA & How is real human insulin made? \\
\hline DNA replication & Why kids look like their parents? \\
\hline Western blotting & How is HIV detected? \\
\hline PCR & How is HIV detected? \\
\hline $\begin{array}{l}\text { Gene mutation and } \\
\text { chemical mutagens }\end{array}$ & $\begin{array}{l}\text { Why is roast meat bad to your } \\
\text { health? }\end{array}$ \\
\hline $\begin{array}{l}\text { Gene mutation and } \\
\text { radiation mutagens }\end{array}$ & Does suntan cause cancer? \\
\hline
\end{tabular}

\section{Results and Discussion}

The above strategies are proven to promote effective learning. As a result, the students in my class express their satisfaction with my teaching style by giving me high marks in student evaluation and by the substantial progress they make. One of the students in my introductory chemistry class said commented "It is very obvious that Dr. Wu wants her students to succeed in this course, not only by making it easy, but also by staying in tune with the students". One commented, "The way she presented the material, made even the more difficult material understandable”.

In order to compare our students' chemical knowledge competency to a national norm, the standardized exams produced by the American Chemical Society's Exam Institute were administered as the final exams. The average score on the organic chemistry exam increased by 16 percentage points from 2008 to 2009 with the highest score of $69 \%$ (the national average is $50 \%$ ). In Biochemistry, our students, scoring average of 37 out of 60 , exceeded the national average (35 out of 60) in 2009 and thus, exceeded the nationally identified benchmark for this exam. This definitely speaks well to manner in which I teach in my class and the ability of our students to compete. Pleasurely suprisely, two students from my 2006 freshmen chemistry class lobbied at a local Burglar King to ban Trans-fat upon learning geometric isomerism and cis-trans conversion at high temperature. I am very grateful for the cooperation and enthusiasm from my students.

Despite the advantages of using overhead transparencies or PowerPoint slides directly, it is notable that there are two significant drawbacks comparing to traditional blacboard instruction. 1) Enormous amount of material delivered per slide; 2) Notebook taking may interfere with listening. In traditional blackboard instruction, an instructor's writing speed sets the pace for students' knowledge process and notebook taking. If the instructor uses pre-made PowerPoint slides, the students may feel to be exposed to overwhelming amount of information at once. In addition, students cannot copy a slide while listening to the instructor's verbal comments and adding the comments and annotation accordingly at the same time. There are several ways to solve the above problems. Posting the lecture slides in advance is one of the solutions to the time constraint. Secondly, Microsoft PowerPoint has built-in "Custom animation" feature which enable us to display objects one at a time [9]. Although the above adjustments are very time consuming, the strategies are extremely rewarding.

Despite the advantages of incorporating analogies into classroom instruction, it is advisable that an analogy may cause confusion by itself in the following two aspects. 1) Students aren't familiar with the analogy that instructors use [18]; 2) Students have a different understanding of the point that the instructors wish to convey. Thus, finding the proper metaphors and repetitively specifying the 
similarities between the concepts and the analogies is necessary.

\section{Conclusions}

In general, inadequate conceptual understanding is one of the common obstacles that college students taking chemistry face. This situation is exacerbated by the lack of incentives and interest. However, an experienced instructor can make chemistry vivid and understandable to attract the interests, which in turn leads to learning enhancement.

\section{References}

[1] J. D. Herron "The Chemistry Classroom: Formulas for Successful Teaching” American Chemical Society: Washington, DC, USA 1996.

[2] D. Bunce, C. Muzzi, "Survival Handbook for the New Chemistry Instructor” Prentice Hall Pub., USA, 2004.

[3] G. M. Bodner, M. Orgill "Theoretical Frameworks for Research in Chemistry/Science Education” Prentice Hall Pub., USA, 2007.

[4] Journal of Chemical Education, American Chemical Society: Washington, DC, USA.

[5] M. Frost, "Correlating Chemistry with Everyday Life", the American Journal of Nursing, USA, 1935 - 35(7), pp 647-648.

[6] P. Furtado, M. Sherwood, C. Sutton, "Chemistry in Everyday Life” Andromeda Oxford, 1991.

[7] F. B. Emery, E. F. Downey, R. E. Davis, C. E. Boynton, "Chemistry in everyday life" Lyons and Carnahan, USA, 1923.

[8] J. T. Moore "Chemistry for dummies" Wiley Pub., USA, 2002.

[9] J. Sloman, "the Lecturing chapter of the 'The Handbook for Economics Lecturers' "The Economics Network of the UK Higher Education Academy, Bristol, UK pp1-26.

[10] L. Pauling, (1932). "The Nature of the Chemical Bond. IV. The Energy of Single Bonds and the Relative Electronegativity of Atoms". Journal of the American Chemical Society 54 (9), pp. 3570-3582.

[11] M. Hudlický, "Reductions in Organic Chemistry" American Chemical Society, Washington, D.C., 1996.

[12] M. Hudlický, "Oxidations in Organic Chemistry" American Chemical Society, Washington, D.C., 1990.

[13] R.Morrison, and R. Boyd, "The resonance hybrid is more stable than any of the contributing structures." Organic Chemistry (Fifth Edition ed.). Prentice Hall of India, 1989. pp. 372.
[14] J. W. Armit, and R. Robinson, "CCXI.—Polynuclear heterocyclic aromatic types. Part II. Some anhydronium bases" Journal of the Chemical Society, Transactions, 1925, 127, pp.1604-1618

[15] J. March, Advanced organic Chemistry, Reactions, mechanisms and structure 3ed. McGraw-Hill Companies, 1977

[16] L. Michaelis, and M.L. Menten, "Kinetik der Invertinwirkung Biochem. Z. 1913; 49:333-369

[17] L. Pauling, "The nature of the chemical bond. Application of results obtained from the quantum mechanics and from a theory of paramagnetic susceptibility to the structure of molecules." Journal of the American Chemical Society,1931, 53(4), pp1367-1400

[18] M.A. Matyas, C.B. Mason, and A.A. Gardener, "Equity, excellence, and 'just plain good teaching."” American Biology Teacher, 1989, 51(2), pp. 72-77. 